\title{
ランチョンセミナー 2
}

\section{(教育講演)}

\section{胚細胞腫瘍の治療における進歩 一泌尿器科領域の経験から一}

\author{
吉川和 行 \\ (東北大学 泌尿器科)
}

精巣肧細胞腫瘍（精巣腫瘍）の治療成績は cisplatin 導入後の多剂併用化学療法の進 歩により飛躍的に向上した。現在，精巣腫瘍は完治が期待できる腫瘍のモデルとなって 和り，進行がんであっても約70\%で化学療法によって根治が得られている。さらに残存 腫瘍に対し手術療法等の salvage therapy を加光ることにより，80～90\%の症例で根治 が期待できるところまできている。しかし，残る治療抵抗性，再発性の症例の対策はい まだ末解決であり，自家骨骾移植，末梢血幹細胞移植など自己造血幹細胞移植を併用し た大量化学療法が試みられ，期待がもたれているが，その評価は定まっていない。

精巣腫瘍の治療成績の向上をもたらした要因をるとめると，

1) 精巣腫瘍に高い感受性を示す cisplatin が化学療法に導入された。

2 ) 精巣腫瘍の腫瘍マーカー (AFP, HCG, HCG- $\beta$ )をより高い感度 $(\mathrm{ng} / \mathrm{ml}$ のレベ ル）で測定できるようになった。

3 ) 画像診断（CT, MRI など）の進歩により転移病巣の拡がりをより客観的に高い精 度で評価できるようになった。

4 ）精巣腫瘍患者が青壮年層の若い人に多いため，侵襲の大きい治療に耐え得る。

5) G-CSF，有用な制吐剤の導入等の支持療法の進歩により，化学療法がより安全に投 与計画通りに行らことができるようになった。 ことがあげられる。

本セミナーでは, 東北大学泌㽷器科での精巣腫瘍の治療経験を踏まえて, 精巣腫瘍の 治療の進歩と治療戦略について検討する。まれではあるが，性腺外肧細胞腫瘍の中では 最も頻度の高い縦隔肧細胞腫瘍の治療を考劣るら劣での一助になれば幸いである。 